\title{
The effects of plant spacing on yield and quality of butterfly pea (Clitoria ternatea L.) cultivated in organic-oriented farming system on grey soil
}

\author{
Duong T. T. Pham*, Tri M. Bui, \& Thuy T. H. Tran
}

Faculty of Agronomy, Nong Lam University, Ho Chi Minh City, Vietnam

ARTICLE INFO
Research Paper
Received: March 30, 2020
Revised: May 10, 2020
Accepted: June 02, 2020
Keywords
Butterfly pea
Clitoria ternatea L.
Grey soil
Organic-oriented farming system
Plant spacing
*Corresponding author
Pham Thi Thuy Duong
Email: pttduong@hcmuaf.edu.vn

Cited as: Pham, D. T. T., Bui, T.M., \& Tran, T. T. H. (2020). The effects of plant spacing on yield and quality of butterfly pea (Clitoria ternatea L.) cultivated in organic-oriented farming system on grey soil. The Journal of Agriculture and Development 19(3), 10-15.

\begin{abstract}
Clitoria ternatea L. is a plant species that can be used in food and pharmaceutical industry. This study was conducted to evaluate the effects of different plant spacing on the productivity and quality of butterfly pea grown on grey soil in Thu Duc, Ho Chi Minh City. Six treatments correspond to plant spacing of $80 \mathrm{x}$ $15 \mathrm{~cm}, 80 \times 20 \mathrm{~cm}, 80 \times 25 \mathrm{~cm}, 80 \times 30 \mathrm{~cm}, 80 \times 35 \mathrm{~cm}$ and $80 \times 40 \mathrm{~cm}$. The results showed that the highest flower amount (296.8 flowers/plant) was obtained with butterfly pea planted at the spacing of $80 \times 15 \mathrm{~cm}$, commercial flower weight $(7.86$ $\mathrm{g} / 100$ flowers $)$, theoretical yield of fresh flower $(1,779.0 \mathrm{~kg} / 1,000$ $\left.\mathrm{m}^{2}\right)$, actual yield of fresh flower $\left(841.9 \mathrm{~kg} / 1,000 \mathrm{~m}^{2}\right)$, theoretical yield of commercial flower $\left(194.6 \mathrm{~kg} / 1,000 \mathrm{~m}^{2}\right)$ and actual yield of commercial flower $\left(89.0 \mathrm{~kg} / 1,000 \mathrm{~m}^{2}\right)$. Nevertheless, plant spacings did not affect the dry matter ratio, anthocyanin and tannin content in the commercial butterfly flowers.
\end{abstract}

\section{Introduction}

Clitoria tenatea L. also known as butterfly pea, is a species belonging to Fabaceae family. Currently, the flowers from butterfly pea are being used in food, medicine as well as in cosmetics (Morris, 2009). Especially, the dried butterfly pea flowers can also be used as tea. Butterfly pea tea is characterized by a rich source of natural antioxidants (Kamkaen \& Wilkinson, 2009), which is also highly safe (Luu, 2005) and satisfied most requirements of the consumers. Consequently, the flowers are consumed increasingly as healthy food. However, the research on farming techniques which are necessary for butterfly pea reaching high yield and quality, are still limited.

Plant spacing is an important determinant of plant growth, development and productivity (McMurray, 2004; McRae et al., 2008; Khaliq et al., 2009). The impact of crop density is mainly due to differences in solar radiation distribution. An optimization of solar radiation uptake is the most important for photosynthetic efficiency. An appropriate plant density or spacing helps plants take advantage of sunlight energy, reducing pests and diseases, paving the way for high productivity. In addition, appropriate spacing can also save the seedlings, labor and other costs, those turn out to improve the economic efficiency. Contreras et al. (2012) concluded that when planting but- 
terfly pea plant with a distance of $25 \times 25 \mathrm{~cm}$ gave highest total grain yield, grain yield per plant, number of pods per plant, number of pods per $\mathrm{m}^{2}$, fruit length, number of seeds in pod as well as the seed weight. However, there is no recommendation for suitable plant spacing for butterfly pea flower used as tea. Therefore, the aim of this research was to identify suitable plant spacing for butterfly pea growing on grey soil in organicoriented farming system.

\section{Materials and Methods}

\subsection{Experimental design}

The experiment was conducted at the Experimental field of Faculty of Agronomy, Nong Lam University, Ho Chi Minh City (September 2019 to January 2020).

The seeds of double-winged butterfly pea variety (collected in Pham Van Coi Commune, $\mathrm{Cu}$ Chi District, Ho Chi Minh City) was sown.

Nutrient used for the whole experiment was well composed cow dung, that supplied by the Experimental field of Animal Science and Veterinary Medicine Faculty, Nong Lam University in Ho Chi Minh city. The manure was applied at a rate of 5.0 tons/ha at 15 days before planting.

Insects and butterflies occurrences on the experimental field were cached manually. No other chemical fertilizers or pesticides was used before and during cultivation period.

One-factor experiment was arranged in a Randomized Completed Block Design (RCBD) included 6 treatments with 3 replicates. The plant spacing in the experiment included: $80 \times 15$ cm $\left(8,333\right.$ plants $\left./ 1,000 \mathrm{~m}^{2}\right), 80 \times 20 \mathrm{~cm}(6,125$ plants $\left./ 1,000 \mathrm{~m}^{2}\right), 80 \times 25 \mathrm{~cm}$ (The control) $(5,000$ plants/1,000 $\left.\mathrm{m}^{2}\right), 80 \times 30 \mathrm{~cm}$ (4,167 plants/1,000 $\left.\mathrm{m}^{2}\right), 80 \times 35 \mathrm{~cm}\left(3,571\right.$ plants $\left./ 1,000 \mathrm{~m}^{2}\right)$ and 80 x $40 \mathrm{~cm}\left(3,125\right.$ plants $\left./ 1,000 \mathrm{~m}^{2}\right)$. Total number of experimental plots was 18 plots; a single plot area was $16.8 \mathrm{~m}^{2}$; The spacing between two neighbouring plots was $0.5 \mathrm{~m}$; The whole experimental area was $302.4 \mathrm{~m}^{2}$.

\subsection{Land preparation and field management}

Beds were established with a size of $6.0 \times 2.8 \mathrm{~m}$, each bed consisted of 3 single rows, each bed was $80 \mathrm{~cm}$ apart and $20 \mathrm{~cm}$ from the aisle; Composted cow dung was applied at the rate of 5 tons/ha 15 days before planting.

Staking setup: U-shaped staking was made of bamboo, with a height of $1.5 \mathrm{~m}$, each row consisted of 7 bamboo poles separated by $1.0 \mathrm{~m}$; a black film was used to cover along the rows for weed preventing.

Seeds were sown on a nursery. After 15 days, the seedlings reached 3 pairs of leaves which then were transplanted onto the experimental field. At 60 days after planting, the plant tips were cut off for branch boosting. Experimental field was watered once/day. Weed control was conducted manually once in every 15 days.

When butterfly pea at flowering stage, new opening flowers were harvested every 2 days. The fresh flowers were left on open air in 48 hours for naturally dryness, then finally, dried at $95^{\circ} \mathrm{C}$ for 40 minutes (Luong, 2004).

\subsection{Data collection and statistics}

Data from following parameters were collected, including:

Total numbers of flowers per plant (flowers/plant): Count the average number of flowers on the target plants at all harvests until the end of the experiment; Fresh flowers weight (g/100 flowers): Weigh 100 fresh flowers at harvest time 60, 75 and 90 days after planting, then average; Commercial flower weight (g/100 flowers): Weigh 100 dried flowers at harvest time 60,75 and 90 days after planting, after drying at $95^{\circ} \mathrm{C}$ for 40 minutes and then average; Theoretical fresh flower yield $\left(\mathrm{kg} / 1,000 \mathrm{~m}^{2}\right)$ : [Total number of flowers/plant (flower/plant) * fresh flower weight $(\mathrm{g} / 100$ flowers) * number of plants $\left./ 1,000 \mathrm{~m}^{2}\right] / 105$; Actual fresh flower yield $\left(\mathrm{kg} / 1,000 \mathrm{~m}^{2}\right)$ : [Total fresh flowers weight/plot $(\mathrm{kg}) \times 1,000] / 16,8$; Theoretical commercial flower yield $\left(\mathrm{kg} / 1,000 \mathrm{~m}^{2}\right)$ : [Total number of flowers/plant (flower/plant) * commercial flower weight (g/100 flowers) * number of plants/1,000 $\left.\mathrm{m}^{2}\right] / 105$; Actual commercial flower yield $\left(\mathrm{kg} / 1,000 \mathrm{~m}^{2}\right)$ : [Total commercial flowers weight/plot $(\mathrm{kg}) \times 1,000] / 16,8$.

Anthocyanin content in commercial flowers was determined using the method TCVN 11028:2015; Tannin content was determined by Leventhal method.

Data analysis was conducted with ANOVA test and Duncan rank at significance level $\alpha=0.01$ using SAS 9.1 software. 
Table 1. Soil characters of the experimental plots ${ }^{1}$

\begin{tabular}{lccl}
\hline Indices & Unit & Result & Method \\
\hline $\mathrm{pH}_{\mathrm{KCl}_{(1: 5)}}$ & $\mathrm{mS} / \mathrm{cm}$ & 5.501 & $\mathrm{pH}$ meter \\
$\mathrm{EC}_{(1: 5)}$ & 0.367 & EC meter \\
Total Organic Car- & $\%$ & 0.718 & Tiurin \\
bon & $\%$ & 0.062 & Kjeldahl \\
Total N & $\mathrm{mg} / 100 \mathrm{~g}$ & 0.597 & Devardar - Alloy \\
$\mathrm{N}^{-\mathrm{NH}_{4}^{+}}$ & $\%$ & 11.581 & \\
$\mathrm{C} / \mathrm{N}$ & $\mathrm{mg} / 100 \mathrm{~g}$ & 4.390 & Bray \#1 \\
Total $\mathrm{P}_{2} \mathrm{O}_{5}$ & $\%$ & 0.154 & Flame photometer \\
Availability $\mathrm{P}_{2} \mathrm{O}_{5}$ & $\mathrm{mg} / 100 \mathrm{~g}$ & 5.085 & Flame photometer \\
Total $\mathrm{K}_{2} \mathrm{O}$ & $\mathrm{meq} / 100 \mathrm{~g}$ & 7.801 & Acetate Amonium \\
Exchangeability & & Sand: 82.20 & \\
$\mathrm{~K}_{2} \mathrm{O}$ & $\%$ & Loam: 13.05 & Densitometrer \\
CEC & & Clay: 4.75 & \\
Soil texture & &
\end{tabular}

${ }^{1}$ Analyzed by Department of Soil Science, Faculty of Agronomy, Nong Lam University, 2019.

Table 2. Amount and mass of butterfly pea flower under the influence of plant spacings

\begin{tabular}{lccc}
\hline Plant spacing $(\mathrm{cm})$ & $\begin{array}{c}\text { Flower amount } \\
\text { (flowers/plant) }\end{array}$ & $\begin{array}{c}\text { Fresh flower weight } \\
(\mathrm{g} / 100 \text { flowers })\end{array}$ & $\begin{array}{c}\text { Commercial flower } \\
\text { weight }(\mathrm{g} / 100 \text { flowers })\end{array}$ \\
\hline $80 \times 15$ & $296.80^{\mathrm{a}}$ & $73.23^{\mathrm{ab}}$ & $7.86^{\mathrm{a}}$ \\
$80 \times 20$ & $290.70^{\mathrm{a}}$ & $73.98^{\mathrm{a}}$ & $7.88^{\mathrm{a}}$ \\
$80 \times 25$ (Control) & $277.23^{\mathrm{a}}$ & $72.95^{\mathrm{ab}}$ & $7.92^{\mathrm{a}}$ \\
$80 \times 30$ & $249.20^{\mathrm{b}}$ & $70.20^{\mathrm{b}}$ & $7.22^{\mathrm{b}}$ \\
$80 \times 35$ & $204.50^{\mathrm{c}}$ & $70.18^{\mathrm{b}}$ & $7.33^{\mathrm{b}}$ \\
$80 \times 40$ & $180.00^{\mathrm{c}}$ & $69.95^{\mathrm{b}}$ & $7.46^{\mathrm{b}}$ \\
\hline CV (\%) & 4.27 & 1.67 & 1.48 \\
F value & $60.93^{* *}$ & $6.95^{* *}$ & $22.77^{* *}$ \\
\hline
\end{tabular}

${ }^{\mathrm{a}-\mathrm{c}}$ In the same column, numbers with the same character are statistically insignificant difference.

**: the difference is statistically significant at $\alpha=0.01$.

\section{Results and Discussions}

\subsection{Evaluation of soil quality at the experi- mental field}

Physical and chemical analysis results of the experimental soil (Table 1) suggested that the experiment plot soil has texture containing $82.20 \%$ of sand, $13.05 \%$ of loam and $4.75 \%$ of clay. According to García-Gaines \& Frankenstein (2015) the soil at the experimental field is belonging to loamy sand texture. The soil was highly acidic $\left(\mathrm{pH}_{\mathrm{KCl}_{(1: 5)}}=5.501\right)$ and not saline $\left(\mathrm{EC}_{(1: 5)}=\right.$ $0.367 \mathrm{mS} / \mathrm{cm}$ ) (Slavich \& Petterson, 1993). It was recommended that the soil $\mathrm{pH}$ ranged from 5.5 to 8.9, which was acceptable for butterfly pea (Singh et al., 2017).
The soil organic C content was low $(0.718 \%)$ and the $\mathrm{C} / \mathrm{N}$ ratio was 11.581 . The soil had low levels of macronutrients (Rayment \& Lyons, 2011). Furthermore, cation exchange capability was also low. However, butterfly pea is a native plant, it is highly adaptable to various soil types therefore this location was acceptable for butterfly pea cultivation. Even those, organic fertilizer supplement is necessary to provide nutrients for plants during cultivation.

\subsection{Influence of plant spacing to amount and mass of butterfly pea flower}

The number of flowers and flower weight are most important factor correlating to butterfly pea flower yield. At the same plant spacing, the 
Table 3. Theoretical and actual yields of butterfly pea under the influence of plant spacing

\begin{tabular}{lcc}
\hline Plant spacing $(\mathrm{cm})$ & $\begin{array}{c}\text { Theoretical fresh flower yield } \\
\left(\mathrm{kg} / 1000 \mathrm{~m}^{2}\right)\end{array}$ & $\begin{array}{c}\text { Actual fresh flower yield } \\
\left(\mathrm{kg} / 1000 \mathrm{~m}^{2}\right)\end{array}$ \\
\hline $80 \times 15$ & $1,812.6^{\mathrm{a}}$ & $841.9^{\mathrm{a}}$ \\
$80 \times 20$ & $1,345.5^{\mathrm{b}}$ & $721.9^{\mathrm{b}}$ \\
$80 \times 25$ (Control) & $1,011.0^{\mathrm{c}}$ & $562.2^{\mathrm{c}}$ \\
$80 \times 30$ & $728.5^{\mathrm{d}}$ & $511.0^{\mathrm{c}}$ \\
$80 \times 35$ & $511.8^{\mathrm{e}}$ & $442.3^{\mathrm{cd}}$ \\
$80 \times 40$ & $395.0^{\mathrm{e}}$ & $371.6^{\mathrm{d}}$ \\
\hline CV $(\%)$ & 6.3 & 7.7 \\
F value & $233.9^{* *}$ & $47.3^{* *}$ \\
\hline
\end{tabular}

${ }^{a-e}$ In the same column, numbers with the same character are statistically insignificant difference.

**: the difference is statistically significant at $\alpha=0.01$.

greater the number of flowers and the heavier weight, the higher the yield will be. Results presented in Table 2 showed that the total number of flowers per plant was significantly different between plants grown at different spacing in the experiment. Planting at the spacing of $80 \times 15 \mathrm{~cm}$ gave the most flowers (296.8 flowers/plant), but not statistically different from the plant spacing of $80 \times 20 \mathrm{~cm}$ (290,70 flowers/plant) and $80 \times 15$ $\mathrm{cm}$ (277.23 flowers/plant). Planting at the spacing of $80 \times 40 \mathrm{~cm}$ obtained lowest number of flowers (only 180 flowers/plant), the difference was 116.80 flowers/plant lower as compared to planting at the spacing of $80 \times 15 \mathrm{~cm}$.

Fresh flower weight and commercial flower weight of butterfly pea plants were significantly different under the influence of different plant spacing. Butterfly pea plants grown at a spacing of $80 \times 20 \mathrm{~cm}$ gained the highest fresh flower weight $(73.98 \mathrm{~g} / 100$ flowers $)$, event it was not statistically different from planting at the spacing of $80 \times 15 \mathrm{~cm}$ or $80 \times 25 \mathrm{~cm}$. The lowest fresh flowers weight gained when planting at the spacing of 80 x $40 \mathrm{~cm}$ (69.95 g/100 flowers). It was 4.03 grams lower than when planting at the spacing of $80 \mathrm{x}$ $15 \mathrm{~cm}$.

Similarly, the highest commercial flower weight of butterfly pea was obtained when planting at the spacing of $80 \times 20 \mathrm{~cm}$ ( $7.88 \mathrm{~g} / 100$ flowers) even it was not statistically different from planting at the spacing of $80 \times 15 \mathrm{~cm}$ or $80 \times 25 \mathrm{~cm}$. Planting at the spacing of $80 \times 40 \mathrm{~cm}$ gained lowest commercial flower weight $(7.46 \mathrm{~g} / 100$ flowers) but which was not statistically different from planting at the spacing of $80 \times 30$ or $80 \times 35 \mathrm{~cm}$; It was only $0.42 \mathrm{~g}$ lower if compared to planting at spacing of $80 \times 15 \mathrm{~cm}$.

Because the experiment conducted at the end of rainy season, most of growth season was during dry and hot weather, plant population at higher density perhaps made microclimate not as hot as in lower density population. The result shown that at higher plant spacing $(80 \times 15 \mathrm{~cm}, 80 \times 20$ $\mathrm{cm}, 80 \times 25 \mathrm{~cm}$ ), butterfly pea plants grown better, giving more flowers and higher flower mass. This result were in accordance with a report by Tran \& Pham (2018) on Limnophila rugosa (Roth) Merr. when they found that growing in a long spacing, especially when the growing substrate covered so it is less affected. Because of high temperature at the experimental area, the plants grew well and formed more leaves.

\subsection{Influence of plant spacing to theoretical and actual yields of butterfly pea}

Results presented in Table 3 shown that butterfly pea grown at the spacing of $80 \times 15 \mathrm{~cm}$ reached highest theoretical yield as well as actual flower yield $(1,812.6$ and $841.9 \mathrm{~kg} / 1,000 \mathrm{~m} 2$, respectively). The actual yield of fresh flowers accounts for $46.4 \%$ of the theoretical fresh flower yield. Besides, butterfly pea grown at the spacing of $80 \times 40 \mathrm{~cm}$, yielding the lowest theoretical and actual fresh flower yields (395.0 and 371.6 $\mathrm{kg} / 1,000 \mathrm{~m}^{2}$, respectively). The actual yield of fresh flowers accounts for $94.1 \%$ of the theoretical fresh flower productivity. The difference in the ratio of actual yield and theoretical yield was due to the level of coverage of the pea plants. When the pea plants were higher density, it might lead to the plants being overlapped. In fact, plants at high density tended to be overlapped each other, which affected to actual numbers of harvestable flowers on the plot. As a consequence, there was a big difference between the theoretical fresh yield 
Table 4. Commercial flower yields of butterfly pea under the influence of plant spacings

\begin{tabular}{lcc}
\hline Plant spacing $(\mathrm{cm})$ & $\begin{array}{c}\text { Theoretical commercial flower } \\
\text { yield }\left(\mathrm{kg} / 1000 \mathrm{~m}^{2}\right)\end{array}$ & $\begin{array}{c}\text { Actual commercial flower yield } \\
\left(\mathrm{kg} / 1000 \mathrm{~m}^{2}\right)\end{array}$ \\
\hline $80 \times 15$ & $194.6^{\mathrm{a}}$ & $89.0^{\mathrm{a}}$ \\
$80 \times 20$ & $143.4^{\mathrm{b}}$ & $75.9^{\mathrm{b}}$ \\
$80 \times 25$ (Control) & $109.8^{\mathrm{c}}$ & $60.1^{\mathrm{c}}$ \\
$80 \times 30$ & $75.0^{\mathrm{d}}$ & $52.5^{\mathrm{cd}}$ \\
$80 \times 35$ & $53.6^{\mathrm{e}}$ & $45.7^{\mathrm{de}}$ \\
$80 \times 40$ & $42.0^{\mathrm{e}}$ & $39.0^{\mathrm{e}}$ \\
\hline $\mathrm{CV}(\%)$ & 5.7 & 7.3 \\
F value & $296.6^{* *}$ & $55.2^{* *}$ \\
\hline a-e In the same column, numbers with the same character are statistically insignificant difference. \\
$* *$ : the difference is statistically significant at $\alpha=0.01$.
\end{tabular}

Table 5. Dry matter, anthocyanin and tannin contents of butterfly pea flowers under influence of plant spacings

\begin{tabular}{lccc}
\hline \multirow{2}{*}{ Plant spacing $(\mathrm{cm})$} & \multicolumn{3}{c}{ Contents $(\%)$} \\
\cline { 2 - 4 } & Dry matter & Anthocyanin & Tannin \\
\hline $80 \times 15$ & 10.753 & 0.538 & 1.817 \\
$80 \times 20$ & 10.661 & 0.546 & 1.824 \\
$80 \times 25$ (control) & 10.856 & 0.538 & 1.820 \\
$80 \times 30$ & 10.295 & 0.540 & 1.824 \\
$80 \times 35$ & 10.490 & 0.540 & 1.827 \\
$80 \times 40$ & 10.635 & 0.536 & 1.829 \\
CV (\%) & 1.930 & 1.745 & 0.483 \\
F value & $2.831^{\text {ns }}$ & $0.380^{\text {ns }}$ & $0.760^{\text {ns }}$ \\
\hline ns: non-significant.
\end{tabular}

and the actual yield. Less shading between plants reduced the difference.

\subsection{Influence of plant spacing to commercial flower yields of butterfly pea}

Commercial flower ratio is a determinant of economic efficiency for the farmers. In this research, butterfly pea flowers were naturally dried for 48 hours at room temperature then transferred to temperature of $95^{\circ} \mathrm{C}$ for $40 \mathrm{~min}$ in order to reach commercial quality level with moisture content was about $12 \%$. The results presented in Table 4 shown that the difference of theoretical and actual commercial flower yield was statistical significance between flower collected from plants grown in different spacing. Butterfly pea plants grown at the spacing of $80 \times 15 \mathrm{~cm}$ obtained the highest theoretical commercial yield (194.6 $\mathrm{kg} / 1000 \mathrm{~m}^{2}$ ); the plants grown at the spacing of $80 \times 40 \mathrm{~cm}\left(42.0 \mathrm{~kg} / 1000 \mathrm{~m}^{2}\right)$, was $152.6 \mathrm{~kg} / 1000$ $\mathrm{m}^{2}$ lower than that.

The actual harvest of commercial flowers was also highest with the butterfly pea planted at the spacing of $80 \times 15$ (reaching $89.0 \mathrm{~kg} / 1,000 \mathrm{~m}^{2}$ ). It was statistically significant higher as compared to plants in all other treatments. Plant grown at the spacing of $80 \times 40 \mathrm{~cm}$, showed the lowest commercial flower $\left(39.0 \mathrm{~kg} / 1,000 \mathrm{~m}^{2}\right)$; it was 40 $\mathrm{kg} / 1,000 \mathrm{~m}^{2}$ lower as compared to plants grown at the spacing $80 \times 15 \mathrm{~cm}$.

In general, it was obvious that the plant density greatly affected to both theoretical and commercial flower yields. The butterfly pea when grown at a higher density obtained a higher yield. At the same time, the difference between theoretical yield and actual yield was high.

\subsection{Influence of plant spacing to dry matter, anthocyanin and tannin contents of but- terfly pea flowers}

Results in Table 5 indicated that different plant spacing did not affect the quality of butterfly pea flower indices including dry matter ratio, anthocyanin and tannin content in dried flowers. The dry matter ratio of the butterfly pea flower ranged from 10.3 to $10.86 \%$. In the commercial 
flowers, anthocyanin content ranged from 0.54 to $0.55 \%$. This result suggested that anthocyanin in butterfly pea flowers is higher than that in some fruits such as blueberries (0.08 to $0.53 \%$ ), cherry ( 0.35 to $0.45 \%)$, black raspberry (0.08 to $0.18 \%$ ) (Horovitz et al., 2008). Anthocyanin related to the intensity of plant colour, the darker the colour, the higher the anthocyanin content. Nevertheless, tannin content in commercial butterfly peas ranged from 1.82 to $1.83 \%$, is much lower than that in black tea $(13.36 \%)$, green tea $(2.65 \%)$ and Oolong tea $(8.66 \%)$ (Khasnabis et al., 2015). Tannin is polyphenol compounds in plants that help to against bacteria and induce acrid taste, it plays an important role in the quality of tea products.

\section{Conclusions}

Pea flower of plants grown at the spacing of $80 \times 15 \mathrm{~cm}$ gained highest number of flowers on plant (296.8 flowers/tree), dry flower weight (7.86 $\mathrm{g} / 100$ flowers), the theoretical fresh flower yield $\left(1,779.0 \mathrm{~kg} / 1,000 \mathrm{~m}^{2}\right)$, the actual fresh flower yield $\left(841.9 \mathrm{~kg} / 1,000 \mathrm{~m}^{2}\right)$, the theoretical commercial flower yield $\left(194.6 \mathrm{~kg} / 1,000 \mathrm{~m}^{2}\right)$ as well as the actual commercial flower yield $(89.0 \mathrm{~kg} / 1,000$ $\mathrm{m}^{2}$ ). The different plant spacing did not affect quality criteria such as dry matter, anthocyanin and tannin content in commercial butterfly pea flower.

\section{References}

Contreras, C. I .M, Torres, B. M. J., Hernández, M. A. S., \& López, M. L. P (2012). Evaluation of plant spacing on seed yield and quality of Clitoria ternatea L. cv. Tehuana. Tropical and Subtropical Agroecosystems 15(3), 489-497.

García-Gaines, R. A., \& Frankenstein, S. (2015). USCS and the USDA soil classification system. Missouri, USA: Engineer Research and Development Center, US Army Crops of Engineer.

Horovitz, M., Kosson, R., Grzesiuk, A., \& Dbski, H. (2008). Anthocyanins of fruits and vegetables - their occurrence, analysis and role in human nutrition. Vegetable Crops Research Bulletin 68, 5-22.
Kamkaen, N., \& Wilkinson, J. M. (2009). The antioxidant activity of Clitoria ternatea flower petal extracts and eye gel. Phytotherapy Research 23, 1624-1625.

Khaliq, T., Ahmad, A., Hussain, A., \& Ali, M. A. (2009). Maize hybrids response to nitrogen rates at multiple locations in semiarid environment. Pakistan Journal of Botany 41(1), 207-224.

Khasnabis, J., Rai, C., \& Roy, A. (2015). Determination of tannin content by titrimetric method from different types of tea. Journal of Chemical and Pharmaceutical Research 7(6), 238-241.

Luong H. Q. (2004). Lecture: Methods of preserving and processing tea. Nong Lam University, Ho Chi Minh City, Vietnam.

Luu, D. C. (2005). Study on extraction of food coloring dyes from experience of using plants of ethnic minorities. Summary report on scientific research topics. Ha Noi National University, Ha Noi, Vietnam.

McMurray, L. (2004). Plant density inputs Kaspa field pea's grain yield. Australian Farm Journal, 45-46.

McRae, F. J., McCaffery, D. W., \& Mathews, P. W. (2008). Winter crop variety sowing guide. NSW Department of Primary Industries, 74-85.

Morris, J. B. (2009). Characterization of butterfly pea (Clitoria ternatea L.) accessions for morphology, phenology, reproduction and potential nutraceutical, pharmaceutical trait utilization. Genetic Resources and Crop Evolution 56(3), 421-427.

Rayment, G. E., \& Lyons, D. J. (2011). Soil chemical methods - Australasia. Collingwood, Australia: CSIRO Publishing.

Singh, N. K., Gupta, J. K., Shah, K., Mishra, P. M., Tripathi, A., Chauhan, N. S., \& Upmanyu, N. (2017). A Review on Clitoria ternatea (Linn.): Chemistry and Pharmacology. Medicinal Plants and its Therapeutic Uses. Hyderabad, India: OMICS International.

Slavich, P. G., \& Petterson, G. H. (1993). Estimating the critical conductivity of saturated paste extracts from 1:5 soil:water suspensions and texture. Australian Journal of Soil Research 31, 73-81.

Tran, V. T., \& Pham, T. T. D. (2018). Effect of subtrates, plant spacing and foliar concentration on growth, yield, and quality of Limnophila rugosa (Roth) Merr. in green house in organic-oriented farming system. Basic Science Research Project, Nong Lam University, Ho Chi Minh City, Vietnam. Code: CS-CB17-NH-02. 